\title{
КЛІНІЧНА ТА ПРОФІЛАКТИЧНА МЕДИЦИНА
}

\author{
DOI 10.31718/2077-1096.21.1.3
}

УДК 616.33-006-089.86-036.8

\section{В’юн С. В., В'юн Т. І., Іванова Ю. В., Битяк С. Ю., Голоборотько М. М. ФОТОДИНАМІЧНА ТЕРАПІЯ У КОМПЛЕКСІ ПЕРЕДОПЕРАЦІЙНОЇ ПІДГОТОВКИ У ПАЦІЄНТІВ З РАКОМ ШЛУНКА}

Харківський національний медичний університет

Проведено вивчення та аналіз результатів лікування 69 пацієнтів у віці від 40 до 85 років (середній

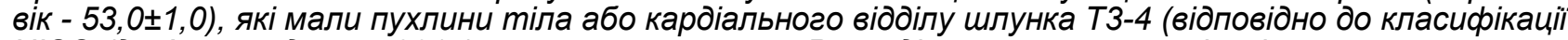
UICC (дев'яте видання, 2014), з високим ризиком. Розподіл хворих за локалізацією пухлинного ураження в шлунку було наступним: в 43 (62,3\%) - в області тіла і у 22 (31,9\%) - в проксимальному відділі (з них у 14 (20,3\%) - в області кардії (III muп по Siewert JR), у 8 (11,6\%) - з переходом на абдомінальний відділ стравоходу (II mип по Siewert JR), в 4 (5,8\%) хворих пухлина розташовувалася в культі резеційованого органу. Гістологічно переважна більшість новоутворень була представлена аденокарциномою (94,8\%). На всі інші види пухлин доводилося 5,2\%. Пацієнти в комплексі лікування отримували фотодинамічну терапію фотосенсибілізатором Фотолон та наступне опромінення за допомогою лазера із довжиною хвилі $\lambda=0,67$ мкм перехрестними полями опромінення, який уводили крізь біопсійний канал ендоскопа. Світлова доза і кількість сеансів опромінення визначалися залежно від ступеня ураження стравоходу та шлунка (від 4 до 7 сеансів). Світлова доза сеансу складала до 200Дж. Щільність потужності лазерного випромінювання - 25 мBm/cм². Ендоскопічна фротодинамічна терапія може бути використана на етапі комбінованого лікування в сполученні з медикаментозною терапією та хірургічним втручанням і $\epsilon$ ефеективним засобом профрілактики розвитку неспроможностей стравохідно-тонкокишкових анастомозів в ранньому післяопераційному періоді. Завдяки проведенню в передопераційному періоді фотодинамічної терапії суттєво знизилась кількість ускладнень в ранньому післяопераційному періоді. Неспроможність стравохідно-кишкового анастомозу розвинулась у 4 випадках, що склало 5, $8 \%$.

Ключові слова: рак шлунка, аденокарцинома, фотодинамічна терапія, фотодинамічна діагностика, неспроможність стравохіднокишкового анастамозу, хірургічне лікування.

Робота виконана в контексті науково-дослідної роботи кафедри хірургії №1 ХНМУ «Удосконалення та розробка методів діагностики і хірургічного лікування захворювань і травм органів черевної порожнини та грудної клітини, судин верхніх та нижніх кінцівок із використанням мініінвазивних методик у пацієнтів на високий ризик розвитку післяопераційних ускладнень», № державної реєстрації $0116 U 004991$.

\section{Вступ}

Зниження ризику високотравматичних операцій з приводу раку шлунка (РШ) і розширення показань до них у пацієнтів з високим ризиком розвитку ускладнень в післяопераційному періоді представляє одну з найактуальніших проблем хірургії [1, 2].

Основний метод лікування РШ - хірургічний. В останні роки для комбінованого лікування стали використовуватися ендоскопічні методи: лазерна деструкція, високочастотна електрорезекція, фотодинамічна терапія (ФДТ) [3, 4, 5]. ФДТпринципово новий метод лікування злоякісних пухлин, заснований на здатності фотосенсибілізаторів селективно накопичуватися в тканині пухлин і при локальному впливі лазерного опромінення певної довжини хвилі генерувати утворення синглетного кисню та інших активних радикалів, які надають токсичний ефект на пухлинні клітини $[6,7]$. Перевагою ряду фотосенсибілізаторів $€$ можливість суміщення в одній процедурі лікування і флуоресцентної діагностики (ФД). Висока вибірковість ураження пухлини при
ФДТ дозволяє мінімально травмувати навколишні здорові тканини, що обумовлює високий функціональний результат лікування [8].

Метою цього дослідження було визначення показань для застосування ендоскопічної ФДТ в лікуванні пацієнтів РШ і ефективності даної методики.

\section{Матеріал та методи дослідження}

Проведено вивчення та аналіз результатів лікування 69 пацієнтів РШ у віці від 40 до 85 років

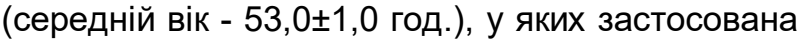
методика ФДТ в комплексі передопераційної підготовки, які перебували на лікуванні в клініці ДУ «IЗНХ їм. В. Т. Зайцева НАМНУ» за період 3 2018 по 2020 рр.

Всі хворі були обстежені за стандартною схемою, що включає: клініко-анамнестичні дослідження, основні клініко-лабораторні та біохімічні показники крові, коагулограма, показники імунограми і спеціальні методи дослідження: електрокардіографрія, рентгенографія органів грудної порожнини і рентгенологічне досліджен- 
ня верхніх відділів шлунково-кишкового тракту 3 використанням контрастної речовини, ультразвукова діагностика органів грудної та черевної порожнин, комп'ютерна томографія органів грудної та черевної підлогу остей з використанням контрастної речовини, відеоендоскопія з забором матеріалу для біопсії і гістоморфологічне дослідження. Отримані дані обробляли методом аналізу таблиць спряженості за допомогою пакета програм Statistica.

\section{Результати дослідження та їх обговорення}

Всі досліджувані пацієнти мали пухлини тіла або кардіального відділу шлунку Т3-4 (відповідно до класифікації UICC (дев'яте видання, 2014). Розподіл хворих за локалізацією пухлинного ураження в шлунку було наступним: в 43 (62,3\%) - в області тіла і у $22(31,9 \%)$ - в проксимальному відділі (з них у 14 (20,3\%) - в області кардії (III тип по Siewert JR), у $8(11,6 \%)$ - з переходом на абдомінальний відділ стравоходу (II тип по Siewert JR), в 4 (5,8\%) хворих пухлина розташовувалася в культі резеційованого органу. За даними гістологічних досліджень переважна більшість новоутворень була представлена аденокарциномою $(94,8 \%)$. На всі інші види пухлин доводилося $5,2 \%$.

У комплексі передопераційної підготовки 69 хворих з РШ і високим ризиком розвитку ускладнень в ранньому післяопераційному періоді, поряд $з$ традиційною передопераційною підготовкою проводилося місцеве лікування, що включало ФДТ. Передопераційна ФДТ виконувалась 3 метою зменшення перифокального запалення, реканалізації при стенозах стравохідношлункового переходу. Інфузія розчину «Фотолона» в дозі 2,5-3,0 мг/кг, розчиненому в 200 мл 0,9\% розчину хлориду натрію проводилася внутрішньовенно на протязі 30 хвилин за 3 години до сеансу ендоскопічного опромінення. Опромінення здійснювалося за допомогою напівпровідникового лазера з довжиною хвилі $\lambda=0,67$ мкм перехресними полями опромінення, що вводиться через біопсійний канал ендоскопа. Світлова доза і кількість сеансів опромінення визначалися залежно від ступеня ураження стравоходу та шлунка (від 4 до 7 сеансів). Світлова доза сеансу складала до 200Дж. Щільність потужності лазерного випромінювання - $25 \mathrm{mBт} / \mathrm{cm}^{2}$.

Переносимість та токсичність препарату Фотолон визначали на підставі клінічного спостереження за хворими і оцінки результатів лабораторних показників крові, сечі в динаміці після введення Фотолона і проведення ФДТ. Клінічне обстеження хворих включало оцінку загального стану хворого, параметрів гемодинаміки (артеріальний тиск, пульс), функції зовнішнього дихання, температури тіла до введення препарату, через 1 і 4 години після введення ФС. Визначався зовнішній вигляд шкіри пацієнта і слизової шлунка і стравоходу, фріксувалося появу алергічних, больових реакцій, токсичних проявів з боку шлунково-кишкового тракту (нудота, блювота) через 1, 4 і 24 год після введення ФС. При клінічному спостереженні за пацієнтами не було виявлено змін їх загального самопочуття, АТ, ЧСС, ЧДД, температури тіла через 1 і 3 години після введення препарату, а також через 1 і 24 години, після проведення ФДТ.

При спектроскопії у хворих було відзначено терапевтичне накопичення препарату, що перевищує його вміст в шкірі і здорової слизової в 1,8-4,3 рази. При наявності великих новоутворень, більше 2 см в діаметрі, відзначалася істотна неоднорідність розподілу препарату в пухлині з посиленням інтенсивності флюоресценції в зонах виразкових дефектів і ерозій. Зона фрлуоресценції у більшості (57 осіб або 82,7\%) хворих перевищувала видимі межі на величину від 0,5 до 2,5 см, а у 9 пацієнтів $(13,0 \%)$ практично збігалася з клінічно визначаються межами пухлини. Додаткові осередки флуоресценції були виявлені у 3 хворих (4,3\%) (2 вогнища), отримана морфологічна верифікація (аденокарцинома).

У процесі сеансу ФДТ спостерігається набряклість, гіперемія зони опромінення з появою геморагічних змін вираженості, після сеансу ФДТ набряки тримаються до 3 днів. Некроз починає формуватися в залежності від розмірів опромінюваної зони через 1-3 дні після лікування у вигляді плівки світлого кольору. Больові відчуття під час сеансу ФДТ у хворих на рак шлунка незначні і не вимагають додаткової анестезії, у хворих з поширенням рецидиву на стравохід спостерігалися більш виражені больові відчуття, печіння в зоні опромінення, тому у них використовувалися додатково ненаркотичні.

При динамічному ендоскопічному спостереженні у всіх досліджуваних пацієнтів виявлено зменшення зон інфільтрації слизової оболонки стравоходу та шлунка (в середньому на 60\%). Слід зазначити що у $12(17,3 \%)$ пацієнтів, що надходили з дисфрагією після проведеного курсу ФДТ частково або повністю куповані явища дисфрагії. Зменшення зони перифокального запалення дало змогу виконати всі оперативні втручання з лапаротомного доступу, при необхідності виконувалась діафрагмотомія за Савіних.

Завдяки проведенню в передопераційному періоді ФДТ суттєво знизилась кількість ускладнень в ранньому післяопераційному періоді. Неспроможність стравохідно-кишкового анастамозу розвинулась у 4 випадках, що склало 5,8\%.

В результаті проведених досліджень було показано, що виконання ФД дозволяє отримувати діагностично значущу інформацію у хворих 3 РШ, визначати межі поширення процесу, виявляти субклінічні вогнища. Відзначено високу чутливість і специфічність методу ФД, проте, враховуючи шкірну фототоксичність препарату, самостійне виконання ФД не рекомендується і може проводитися одночасно з ФДТ [6]. ФДТ $€$ ефективним способом передопераційної підготовки хворих з раком шлунка і призводить до хо- 
рошого функціонального результату лікування, зменшенню зон запальної і пухлинної інфільтрації і може використовуватися в комбінації з традиційними методами терапії [8]. Зменшення зони перифокального запалення дало змогу виконати всі оперативні втручання з лапаротомного доступу, при необхідності виконувалась діафрагмотомія за Савіних [2]. ФДТ може використовуватися при неможливості хірургічного лікування у хворих з важкою супутньою патологією.

\section{Висновки}

Фотодинамічна терапія із застосуванням в якості фотосенсибілізатора препарату «Фотолон» $є$ високоефективною методикою передопераційної підготовки у хворих з раком шлунку, а також може бути використана в післяопераційному періоді з метою профілактики розвитку неспроможності анастомозів і підвищення рівня безрецидивного виживання.

При динамічному ендоскопічному спостереженні у всіх досліджуваних пацієнтів виявлено зменшення зон інфільтрації слизової оболонки стравоходу та шлунка (в середньому на 60\%).

Зменшення зони перифокального запалення в результаті застосування фоотодинамічної терапії дало змогу виконати всі оперативні втручання з лапаротомного доступу.
Перспективи подальшого дослідження з цієї проблематики пов'язані з обґрунтуванням показань для застосування ендоскопічної фотодинамічної терапії в лікуванні пацієнтів на рак шлунка і ефективності даної методики.

\section{References}

1. Davydov MI, Ter-Ovanesov MD, Abdikhakimov AN. Rak zheludka: predoperatsionnoe obsledovanie i aktualnye voprosy stadirovaniya [Stomach cancer: preoperative examination and current staging issues]. Prakticheskaya onkologiya. 2020; 3: 9-17. (Russian)

2. Besova NS, Byakhov MYu, Gorbunova VA, Davydov MI, Davydov $\mathrm{MM}$, Karseladze Al, et al. Klinicheskie rekomendatsii po diagnostike i lecheniyu bolnykh rakom zheludka [Clinical guidelines for the diagnosis and treatment of patients with stomach cancer]. M; 2017. 21 s. (Russian)

3. Filonenko EV. Flyuorestsentnaya diagnostika i fotodinamicheskaya terapiya - obosnovanie primeneniya i vozmozhnosti $\vee$ onkologii [Fluorescence diagnostics and photodynamic therapy - rationale for the use and possibilities in oncology]. Fotodinamicheskaya terapiya i fotodiagnostika. 2014; 1: 3-7. (Russian)

4. Tsyb AF, Kaplan MA, Romanko YuS, Popuchiev VV. Fotodinamicheskaya terapiya [Photodynamic therapy]. M: MIA; 2015. 235 s. (Russian)

5. Nishiwaki Y, Kida H, Waki S. Outcome of photodynamic therapy for gastric cancer. 9 World Congress of the International Photodynamic Association. 2019. p. 37

6. Mimura S. Progress of photodynamic therapy in gastric cancer. 9 World Congress of the International Photodynamic Assocoation. 2019. p. 36 .

7. Agostinis P, Berg K, Cengel KA, Foster TH, Girotti AW, Gollnick $\mathrm{SO}$, et al. Photodynamic therapy of cancer: an update. CA Cancer J Clin. 2019; 61(4): 250-281.

8. Celli JP, Spring BQ, Rizvi I, Evans CL, Samkoe KS, Verma S, et al. Imaging and photodynamic therapy: mechanisms, monitoring, and optimization. Chem Rev. 2020; 110(5): 2795-2838.

\section{Реферат}

ФОТОДИНАМИЧЕСКАЯ ТЕРАПИЯ В КОМПЛЕКСЕ ПРЕДОПЕРАЦИОННОЙ ПОДГОТОВКИ У ПАЦИЕНТОВ С РАКОМ ЖЕЛУДКА Вьюн С. В., Вьюн Т. И., Иванова Ю. В., Битяк С. Ю., Голоборотько Н. Н.

Ключевые слова: рак желудка, аденокарцинома, фотодинамическая терапия, фотодинамическая диагностика, несостоятельность пищеводно-кишечного анастомоза, хирургическое лечение.

Проведено изучение и анализ результатов лечения 69 пациентов в возрасте от 40 до 85 лет (сре-

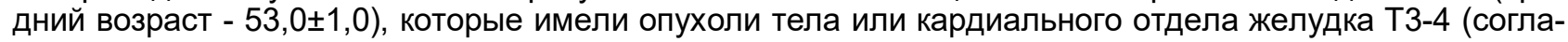
сно классификации UICC (девятое издание, 2014), с высоким риском. Распределение больных по локализации опухолевого поражения в желудке было следующим: в $43(62,3 \%)$ - в области тела и у 22 (31,9\%) - в проксимальном отделе (из них у 14 (20 3\%) - в области кардии (III тип по Siewert JR), у 8 (11,6\%) - с переходом на абдоминальный отдел пищевода (II тип по Siewert JR), в 4 (5,8\%) больных опухоль располагалась в культе резецированного органа. Гистологически подавляющее большинство новообразований было представлено аденокарциномой (94,8\%). На все остальные виды опухолей приходилось 5,2\%. Пациенты в комплексе лечения получали фотодинамическую терапию фотосенсибилизатором Фотолон и последующее облучение с помощью лазера с длиной волны $\lambda=0,67$ мкм перекрестных полями облучения, который вводили через биопсийный канал эндоскопа. Световая доза и количество сеансов облучения определялись в зависимости от степени поражения пищевода и желудка (от 4 до 7 сеансов). Световая доза сеанса составляла до 200 Дж. Плотность мощности лазерного излучения - 25 мВт/см². Эндоскопическая фотодинамическая терапия может быть использована на этапе комбинированного лечения в сочетании с медикаментозной терапией и хирургическим вмешательством, и является эффективным средством профилактики развития несостоятельности пищеводно-тонкокишечного анастомоза в раннем послеоперационном периоде. Благодаря проведению в предоперационном периоде фотодинамической терапии существенно снизилось количество осложнений в раннем послеоперационном периоде. Несостоятельность пищеводно-кишечного анастомоза развилась в 4 случаях, что составило $5,8 \%$.

\section{Summary}

PHOTODYNAMIC THERAPY AS A COMPONENT OF PREOPERATIVE PREPARATION FOR PATIENTS WITH STOMACH CANCER Viun S. V., Viun T. I., Ivanova Yu. V., Bityak S. Yu., Holoborotko N. N.

Key words: stomach cancer, adenocarcinoma, photodynamic therapy, photodynamic diagnosis, failure of esophageal-intestinal anastamosis, surgical treatment.

The study and analysis of the treatment outcomes were carried out in 69 patients aged from 40 to 85

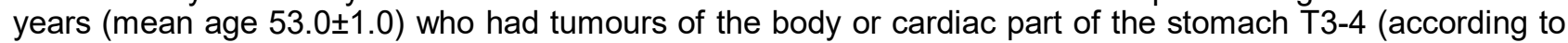
the UICC classification (ninth edition, 2014)). The distribution of patients according to the localization of 
tumour lesions in the stomach was as follows: $43(62.3 \%)$ cases found in the body region and $22(31.9 \%)$ found in the proximal section (of which $14(203 \%)$ were in the cardia (Type III according to Siewert J.R.), 8 (11.6\%) patients had the transition to the abdominal oesophagus (type II according to Siewert JR), 4 (5.8\%) patients had the tumour located in the stump of the resected organ. Histologically, the vast majority of neoplasms were represented by adenocarcinoma (94.8\%). All other types of tumours made up for $5.2 \%$. The patients received photodynamic therapy with the Photolon photosensitizer and subsequent irradiation with a laser with a wavelength $\lambda=0.67 \mu \mathrm{m}$ crossed irradiation fields, which was introduced through the biopsy channel of the endoscope. The light dose and the number of irradiation sessions were determined depending on the degree of damage to the oesophagus and stomach (from 4 to 7 sessions). The light dose of the session was up to $200 \mathrm{~J}$. The power density of the laser radiation is $25 \mathrm{~mW} / \mathrm{cm}^{2}$. Endoscopic photodynamic therapy can be used at the stage of combined treatment in combination with chemotherapy and surgery and is an effective means of preventing the failure of the oesophageal-small intestinal anastomosis in the early postoperative period. Due to photodynamic therapy in the preoperative period, the number of complications in the early postoperative period has significantly decreased. The leakage of the oesophageal-intestinal anastomosis developed in 4 cases, which make up 5.8\%.

DOI 10.31718/2077-1096.21.1.6

УДК 616.12-005.4:616.132.2-085

Гогаєва O.K.

ОСОБЛИВОСТІ МЕДИКАМЕНТОЗНОЇ ТЕРАПIÏ ПАЦІЄНТІВ З ІХС ВИСОКОГО РИЗИКУ ПІСЛЯ ВІНЦЕВОГО ШУНТУВАННЯ

ДУ «Національний Інститут серцево-судинної хірургії ім. М.М. Амосова НАМН України», м. Київ

3 кожним роком зростає кількість хворих, яким виконана хірургічна реваскуляризація міокарда. З'являються нові регіональні центри, а перед кардіологом стає важливе питання ведення пацієнтів після кардіохірургічного втручання. Мета: проаналізувати особливості медикаментозної терапії хворих на ішемічну хворобу серия з високим ризиком після хірургічної реваскуляризації міокарду. Матеріал і методи: Проведено ретроспективний аналіз даних 194 пацієнтів (відібраних методом випадкової вибірки) з високим ризиком, які були прооперовані та виписані з Національного Інституту серцево-судинної хірургії ім. М.М. Амосова Національної Академії Медичних Наук України в період 2009-2019 рр. Середній вік хворих становив 64,2+8,9 років. Всім пацієнтам проведені: стандартні лабораторно-клінічні дослідження, коронарографія та вінцеве шунтування. Результати: На тлі синусового ритму оптимальним є призначення подвійної антиагрегантної терапії. При наявності фрібриляції передсердь рекомендована комбінація антиагреганта з антагоністом вітаміну К або нові оральні антикоагулянти. Ліпідознижуюча терапія ініціюється всім пацієнтам до оперативного втручання в повній дозі під контролем ліпопротеїдів низької щільності, печінкових ферментів та сироваткого креатиніну. Гастропротективна терапія пантопразолом повинна проводитись всім пацієнтам після реваскуляризації міокарду. При призначенні антигіпертензивної терапії в післяопераційному періоді важливо враховувати ступінь стенозу брахіоцефральних артерій. Висновки: Медикаментозне лікування пацієнтів після операції коронарного шунтування має проводитись персоналізовано та за принципом "Non nocere" - не нашкодь з урахуванням кардіального статусу та коморбідної патології.

Ключові слова: ішемічна хвороба серця, пацієнт високого ризику, вінцеве шунтування, працююче серце, медикаментозна терапія, подвійна антиагрегантна терапія.

Зв'язок роботи з науковою темою «Розробити та впровадити систему попередження ускладнень та підвищити ефективність хірургічного лікування IXC у пацієнтів високого ризику» (номер державної реєстрації 0120U103769).

3 кожним роком зростає кількість хворих, яким виконана хірургічна реваскуляризація міокарда. З'являються нові регіональні центри, а перед кардіологом стає важливе питання ведення пацієнтів після кардіохірургічного втручання. Особливості проведення оперативного втручання, раннього післяопераційного періоду та коморбідних станів впливають на схему медикаментозної терапії. За літературними даними призначення ацетилсаліцилової кислоти (АСК) протягом 6 годин після коронарного шунтування (КШ) сприяє поліпшенню прохідності шунтів, запобігає несприятливим серцево-судинним подіям та покращує довготривале виживання $[1,2]$. Також до- сліджують роль інших антиагрегантів, включаючи клопідогрель, після хірургічного втручання для запобігання оклюзії трансплантата та уповільнення прогресування атеросклеротичних уражень нативних вінцевих артерій $[3,4]$. Спостерігають незначне поліпшення прохідності венозного шунта при додаванні клопідогрелю до АСК після КШ на працюючому серці [2, 4], але деякі автори не виявили ніякої користі від призначення клопідогрелю після операції. При аналізі даних більше 25000 пацієнтів Deо зі співавторами повідомили, що додавання клопідогрелю до АСК знижує ризик оклюзії венозного шунта на $41 \%$ $(p=0,02)$, але ціною підвищеного ризику кровотеч 